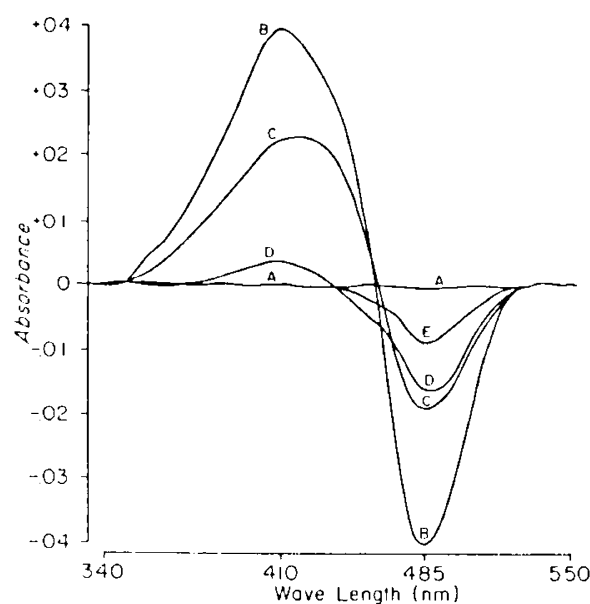

Fig. 9. Perturbations of the bilirubin-albumin absorption spectrum as measured by difference spectra. A, base line (conditions are identical in sample and reference). B, bilirubin, 4 .0 $\mu$ mol/liter in sample and reference (sample has no albumin, reference has albumin. 8 mol/liter; i.c., the spectrum of unbound $v$ s. bound bilirubin). $C$, bilirubin and albumin $=10 \mu \mathrm{mol} /$ liter (molar ratio 1.0), sulfisoxazole $(10.6 \mathrm{mg} / 100 \mathrm{ml} \mathrm{in}$ sample). D, bilirubin and albumin. $10 \mu \mathrm{mol} / \mathrm{liter}$, amino acids $(500 \mathrm{mg} /$ $100 \mathrm{ml}$ ) in sample. E, bilirubin, $10 \mu \mathrm{mol} / \mathrm{liter}$; albumin, $100 \mu \mathrm{mol} / \mathrm{liter}$ in sample (molar ratio 0.1$)$ and $20 \mu \mathrm{mol} /$ liter in reference (molar ratio 0.5 ); the decrease at $485 \mathrm{~mm}$ is not accompanied by a change in absorbance at $410 \mathrm{~nm}$.

spectrum of bilirubin $(1,7,8)$ must be made with great caution and only under well controlled conditions.

\section{CONCLUSION}

The results of these studies indicate that certain amino acids interact with human albumin inducing slight spectral alterations in the bilirubin: albumin complex. At high molar ratios of bilirubin:albumin and in the presence of high amino acid concentrations, displacement of bilirubin occurs, but the magnitude of displacement is small. Thus, the administration of parenteral solutions containing amino acids to sick infants with unconjugated hyperbilirubinemia would be unlikely to increase the risk of bilirubin encephalopithy.

\section{REFERENCES AND NOTES}

1. Coutinho, C. B., Lucek, R. W., Cheripho, J. A., and Kuntzman, R.: A new approach to the determination of protein-bound bilirubin-displacement and its applications. Ann. N. Y. Acad. Sci., 226: 238 (1973).

2. Driscoll, J. M., Jr., Heird, W. C., Schullinger, J. N., Gongaware, R. D., and Winters, R. W.: Total intravenous alimentation in low-birth-weight infants: A preliminary report. J. Pediat., 81: 145 (1972).

3. Gustafsson, A., Kjellmer, I., Olegard, R., and Victorin, L: Nutrition in lowbirth weight infant. Acta Pediat. Scand., 61: 149 (1972).

4. Jacobsen, J.: Binding of bilirubin to human serum albumin. Fed. Eur. Biochem. Soc. Lett., 5: $112(1969)$.

5. Jacobsen, J., and Wennberg, R. P.: Determination of unbound bilirubin in the serum of newborns. Clin. Chem., 20: 783 (1974).

6. Malloy, II. T., and Evelyn, K. A.: The determination of hilirubin with the photoelectric colorimeter. J. Biol. Chem., 1/9: 481 (1937).

7. Odell, G. B.: Dissociation of bilirubin from albumin and its clinical implications. J. Pediat., 55: 268 (1959).

8. Odell, G. B.: Studies in kernicterus. I. The protein binding of bilirubin. J. Clin. Invest., 38: 823 (1959).

9. Ostrow, J. D.. Hammaker, L., and Schmid, R.: The preparation of crystalline bilirubin-C ${ }^{14}$. J. Clin. Invest., 40: 1442 (1961).

10. Schmid, R., Diamond, I., Hammaker, L.. Gunderson, C. B.: Interaction of bilirubin with albumin. Nature, 206: 1041 (1965).

11. Silverman, W. A., Anderson, D. H., Blanc, W. A., and Crozier, D. N.: A difference in mortality rate and incidence of kernicterus among premature infants allotted to two prophylactic antibacterial regimens. Pediatrics, 18: $614(1956)$.

12. Questran, Mead-Johnson.

13. This research was supported in part by United States Public Health Service Grant HD-(03148 and HD-(04665 and by United Cerebral Palsy grants R263 and $\mathrm{R}-265$.

14. Requests for reprints should be addressed to: M. M. Thaler, M.D., Department of Pediatrics, School of Medicine. University of Californa, San Francisco, Calif. 94143 (USA)

15. Received for publication Februaty 20,1976

16. Accepted for publication August 26,1976 .

\title{
Influence of Intravenous Nutrients on Bilirubin Transport. II. Emulsified Lipid Solutions
}

\author{
M. MICHAEL THALER(':-2) AND) RICHARI) P. WENNBERG \\ Department of Pe'diatrics and Liver Research Center, University of California, San Francisco and Department of \\ Pediatrics, University of California, Davis, California, USA
}

\section{Summary}

The effects of an emulsified intravenous fat preparation (Intralipid) on bilirubin transport were analyzed by cholestyramine extraction, spectrophotometric analysis, Sephadex gel filtration, peroxidase assay, bilirubin uptake by red blood cells, and by toxicity in tissue culture (L-929) cells. Intralipid is capable of binding bilirubin, but does not compete effectively with bilirubin bound to high affinity sites on albumin. The emulsified fat appears to have a higher affinity for bilirubin than for cell membranes. Red blood cells become coated with Intralipid, resulting in an increased association of bilirubin with the cell 
surface, but a decrease in pigment actually incorporated into the red cell membrane. In tissue culture experiments, Intralipid protected the cells from bilirubin toxicity. It is concluded that Intralipid may enhance the carrying capacity of serum for bilirubin, and thus exert a protective effect on tissues.

\section{Speculation}

limulsified fat appears to interact with serum bilirubin not bound (or loosely bound) to albumin. Higher affinity for bilirubin of Intralipid compared with cellular surface membranes suggests that emulsified fat infusions may act as a temporary barricr to entry of bilirubin into tissues.

Intravenous administration of fat is a potentially useful means of supplying calories to malnourished newborn infants and patients with severe gastrointestinal deficiencies $(1,6,7,20)$. Premature infants treated with an emulsified fat infusion have demonstrated weight gain which closely approximated the intrauterine growth rate $(3,8,13)$. Most newborn infants and premature infants clear emulsified fat rapidly, although a decreased clearance has been noticed in some premature and small for date newborns $(8,18)$. Since bilirubin may form complexes with lipids (10, 11), infused fat emulsion could interfere with bilirubin transport and binding to plasma albumin. For these reasoms we have investigated the effects of fat emulsion on albumin binding and on bilirubin distribution between albumin and tissue.

\section{MATIERIALS AND METHODS}

Intralipid (obtained from Cutter Laboratories, Berkeley, (alif.) is an emulsified fat preparation containing $10 \%$ soy bean oil, $1.2 \%$ ege phospholipids, $2.25 \%$ glycerin, and pyrogen-free water with an osmolatity of $280 \mathrm{mOsm}$ /liter. Various concentrations of Intralipid were diluted in isotonic phosphate buffer, pH 7.4. Bilirubin-albumin solutions were prepared by dissolving bilirubin in $0.05 \mathrm{~N} \mathrm{NaOH}$, and then mixing with a solution of purified human serum albumin (fraction V, Sigma) or crystalline albumin (Cutter). All experiments were conducted in $0.055 \mathrm{M}$ phosphate buffer, pH 7.t, except for tissue culture experiments, which were performed in HEPES-buffered Hanks' solution, pll 7.4, at $37^{\circ}$. Crystalline l"C $^{\prime}$ bilirubin was prepared by the method of Ostrowet al. (12). All experiments were performed in subdued light.

Spectrophotometric analysis of bilirubin-albumin and bilirubin-Intralipid complexes were performed using a Cary model 16 recording spectrophotometer with a high intensity light souree. Studies were conducted at $27^{\circ}$.

Cholestyramine resin binding was performed using a procedure modified from Schmid at al. (14). Each incubation flask contained a solution of bilirubin-albumin at a molar ratio of $2: 1$, including $3 \mu \mathrm{g}\left[{ }^{\mathrm{H}} \mathrm{C}\right.$ bilirubin (specific activity $26.0(0)(\mathrm{dpm} / \mu \mathrm{g}$ ) and Intralipid at a final concentration of $1,000 \mathrm{mg} / \mathrm{l}(0) \mathrm{ml}$. A prewashed suspension of buffered cholestyramine or cholestyramine pretreated with Intralipid $(10 \mathrm{mg} / 100 \mathrm{mg}$ resin) was added with constant stirring. Aliquots removed at specified intervals were inmediately filtered free of resin and the pigment remaining in solution was measured by counting the radioactivity in the clear filtrate. Control incubations contained all components with the exception of Intralipid, which was replaced by an equivalent volume of buffer. Studies of the interaction between bilirubin and Intralipid in the absence of albumin were conducted using a ${ }^{14} \mathrm{C}$ bilirubin concentration of $9 \mathrm{mg} / \mathrm{l} 00 \mathrm{ml}$.

Sephadex G-25 gel filtration, the peroxidase assay for unbound bilirubin, and red cell uptake of bilirubin were performed as previously described (9.19).

Cell toxicity was evaluated in cultured L cells. L_-929 cells were grown with $5 \%$ CO. and air in Eagle's minimal essential medium containing Hanks' balanced salt solution and $5 \%$ fetal calf serum. Cells were harvested by seraping and diluted to 100 cells/ml with medium. One-milliliter aliquots of cell suspension were pipetted into $35-\mathrm{mm}$ plastic Falcon dishes and allowed to attach overnight. On the following day, the plates were washed three times with $1 \mathrm{ml}$ HEPES-buffered Ilanks" solution, pH 7.4 . containing $1.5 \mathrm{~g} / 100 \mathrm{ml}$ albumin and various concentrations of bilirubin, and incubated in the dark at $37^{\circ}$. After a $6(0)$-min incubation, the cells were washed twice with tissue culture medium and allowed to grow for 3 days. The cells were fixed, stained with Giemsa, and colonies were counted. The plates were exposed either to albumin or albumin and bilirubin, with or without the presence of Intralipid. Three test plates were incubated and counted for each set of experimental conditions. Viabilities were calculated by dividing the mean colony count of the bilirubin-exposed cultures by the mean colony count of appropriate control plates. The mean coefficient of variation in counting was $21 \%$ \%

\section{RISULTS}

\section{INTERACTION OF BILIRUBIN WITH INTRALIPID}

The influence of Intralipid on the absorption spectrum of aqueous bilirubin is illustrated in Figure 1. Bilirubin forms an unstable solution at pH 7.4 and is thought to have a solubility of approximately $1 \mu \mathrm{mol} / \mathrm{liter}(2)$. The initial bilirubin coneentration was $12.5 \mu \mathrm{mol} / \mathrm{liter}$; in the absence of Intralipid, the absorptivity declined slowly over a period of hours as colloidal bilirubin formed. This process was greatly accelerated in the presence of very low concentrations of Intralipid $(0.12 \mathrm{mg} / \mathrm{l}(0)$ mi) (Fig. 1, B). The mixture became turbid over a period of 3-4 min and, on microscopic examination, angeregates of heavily stained lipid particles were observed. As the concentration of Intralipid increased beyond $1 \mathrm{mg} / \mathrm{lo0} \mathrm{ml}$, however, increased turbidity was not visually observed, bilirubin did not precipitate even with shaking (in contrast to agueous bilirubin), and the absorption spectrum assumed the characteristics of bilirubin bound to mitochondria as reported by Mustafa and King (11). Greater increase in the Intralipid concentration produced a gradual shift in the absorption spectrum approaching that of bilirubin dissolved in chloroform or olive oil.

Ayueous solutions of bilirubin at pH 7.4 (no albumin) were rapidly cleared of pigment by both pretreated and untreated cholestyramine resin (Fig. 2). Intralipid, however, inhibited the removal of bilirubin from solution.

\section{INELUI:NCE (OF INTRALIPID ON ALBUNIN BINI)ING OF BHIRUBIN}

Intralipid had no detectable effect on the absorption spectrum of bilirubin bound to human serum albumin (fraction V) until

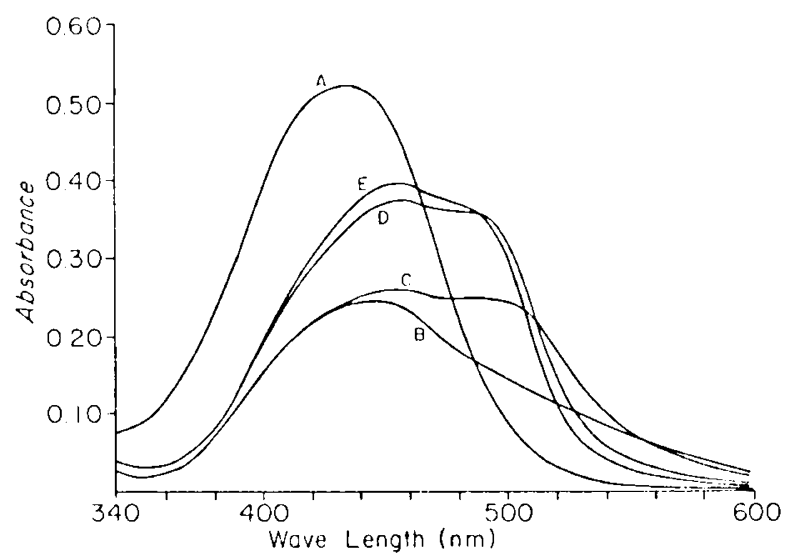

Fig. 1. Effects of Intralipid on the absorption spectrum of hilirubin. Solutions contained phosphate buffer, pH 7.4 , and bilirubin, $12.5 \mu \mathrm{mol} /$ liter. Intralipid concentration was $(A) 0 \mathrm{mg} / 100 \mathrm{ml}$, (B) $0.125 \mathrm{mg} / 100$ $\mathrm{ml}$, (C) $1.0 \mathrm{mg} / 100 \mathrm{ml}$, (D) $4.0 \mathrm{mg} / 100 \mathrm{ml}$, (1E) $128 \mathrm{mg} / 100 \mathrm{ml}$. 


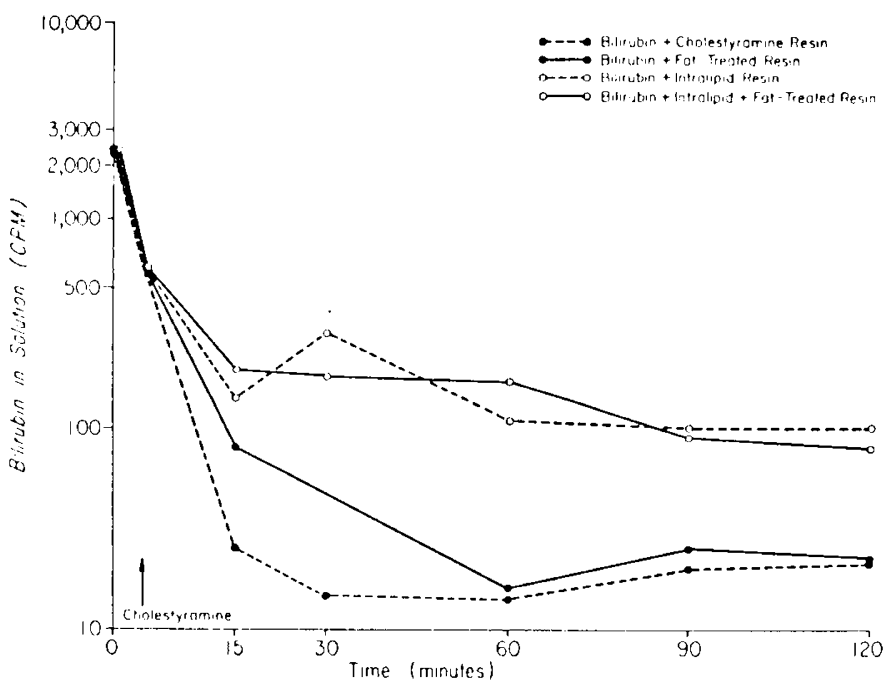

Fig. 2. Effects of Intralipid on cholestyraminc extraction of bilirubin Representative of six individual experiments. Solutions contained bilirubin and phosphate buffer, pH 7.4, but no albumin.

Table 1. Effects of Intralipid on albumin binding of bilirubin: Spectrophotometric analysis

Ratio of absorbance, $490 \mathrm{~nm} /$ $460 \mathrm{~mm}$

\begin{tabular}{cccc}
$\begin{array}{c}\text { Molar ratio, bilirubin- } \\
\text { albumin }\end{array}$ & \multicolumn{2}{c}{$\begin{array}{c}\text { Intralipid. } 34 \mathrm{mg} / \\
100 \mathrm{ml}\end{array}$} & Change in ratio \\
\hline 0.5 & 0.54 & 0.53 & -0.01 \\
0.8 & 0.54 & 0.57 & +0.03 \\
1.2 & 0.54 & 0.59 & +0.05 \\
2.0 & 0.53 & 0.59 & +0.05 \\
No albumin & 0.39 & 0.98 & +0.59 \\
\hline
\end{tabular}

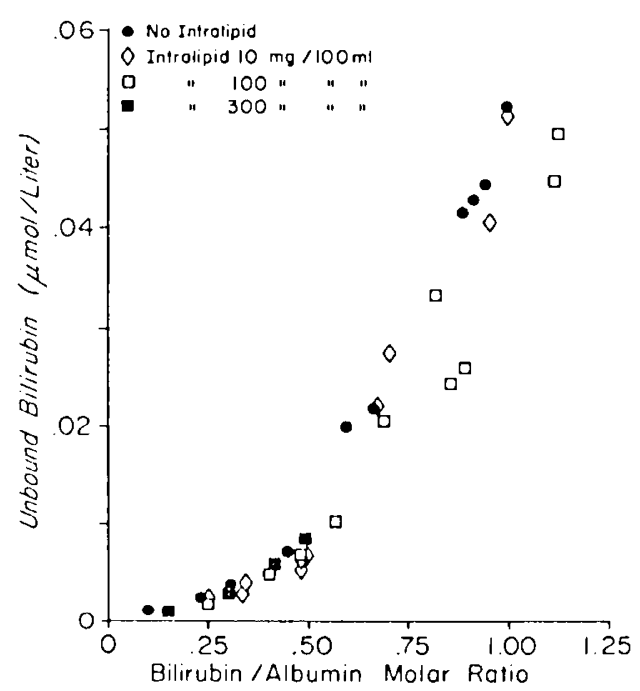

Fig. 3. Effect of Intralipid on the unbeund bilirubin concentration. Solutions contained phosphate buffer, pH 7.4 , albumin $20 \mu \mathrm{mol} / \mathrm{liter}$, and various bilirubin concentrations. Peroxidase assays were performed at $27^{\circ}$.

the molar ratio of bilirubin to albumin approached $1: 1$. Even with a molar ratio 2:1, alterations in the absorption spectrum were minimal (Table 1).

The peroxidase assay was used to detect small changes in unbound bilirubin before the molar ratio (bilirubin-albumin) reached $1: 1$ (i.e., in the bilirubin concentration range usually observed in clinical situations). The effect of Intralipid on the unbound bilirubin concentration at various molar ratios of bilirubin to albumin is summarized in Figure 3. Intralipid had little influence on the concentration of unbound bilirubin until the molar ratio of bilirubin to albumin exeeceded 1:1, after which lower unbound bilirubin concentrations were observed in the presence of Intralipid.

Less bilirubin became associated with cholestyramine resin in the reaction mixture in the presence of Intralipid than when no Intralipid was added (Fig. 4), indicating that fat interfered with transfer of pigment from albumin to resin. Pretreatment of cholestyramine with Intralipid did not change the affinity of the resin for bilirubin, suggesting that the slower uptake of bilirubin in the presence of Intralipid was not due to competition between lipid and pigment for binding sites on the resin.

Binding of bilirubin to albumin at a molar ratio of $2: 1$ was stronger than binding of bilirubin to emulsified fat. Immediately after addition of resin to the bilirubin-albumin solution, 10 \% of the pigment was removed from solution, compared with $25 \%$ removed from the buffered bilirubin-Intralipid suspension. As seen by comparing Figures 2 and 4 , twice as much bilirubin was maintained in solution by albumin compared with Intralipid after $30 \mathrm{~min}$ of incubation. Albumin and Intralipid in combination appeared to have an additive effect on the ability of bilirubin to stay in solution (Fig. 4).

Analogous results were obtained with Sephadex filtration. Rather than causing increased displacement of bilirubin from albumin. Intralipid actually decreased the amount of bilirubin staining the gel (Fig. 5). A portion of the filtered bilirubin was presumably bound to the Intralipid.

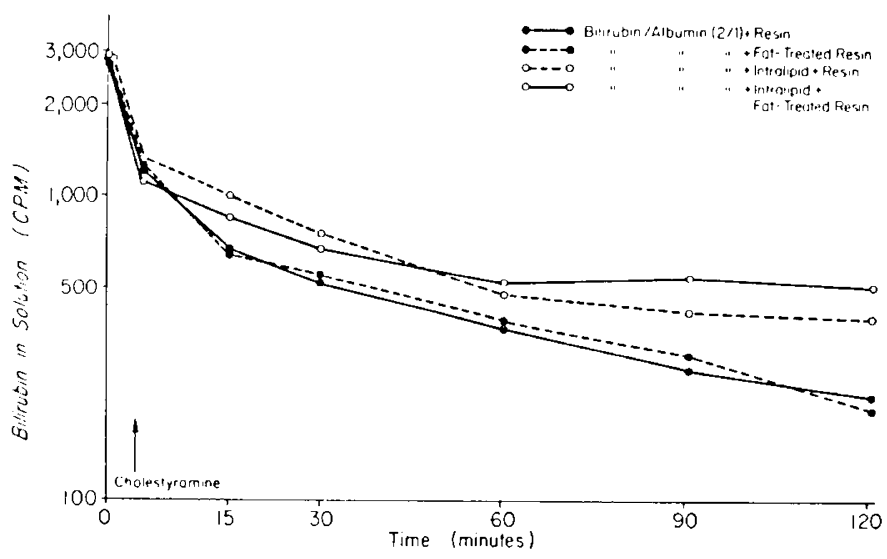

Fig. 4. Cholestyramine extraction of bilirubin in the presence of albumin. Representative of eight individual experiments.

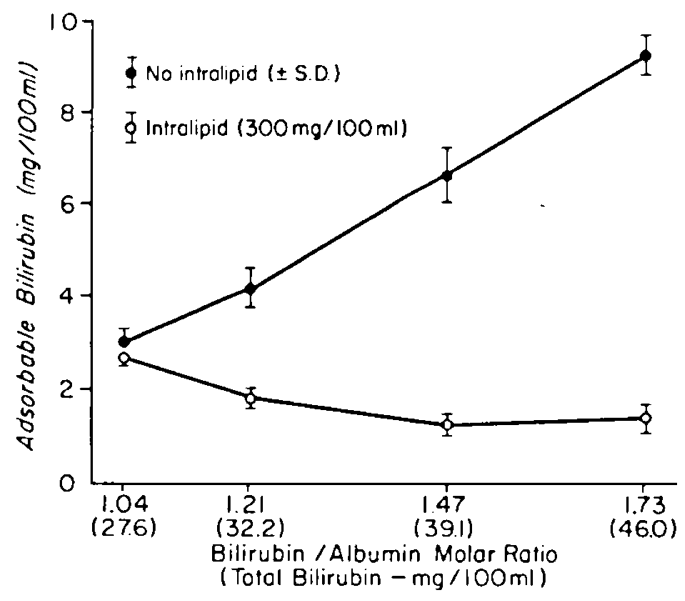

Fig. 5. Sephadex G-25 gel filtration. Bilirubin adsorbed by the gel was eluted with albumin. 
IFFIE ("TS OF INIRALIPII) ON BILIRUBBIN TRANSPORT

In the absence of Intralipid, the amount of bilirubin adsorbed by red cells depended on the bilirubin-albumin molar ratio in plasma (Fig. 6). Approximately $7 \%$ of the pigment in the plasma was removed by red cells at a bilirubin to albumin ratio of 0.4 , compared with $22 \%$ of a molar ratio of 1.4 . Intralipid produced

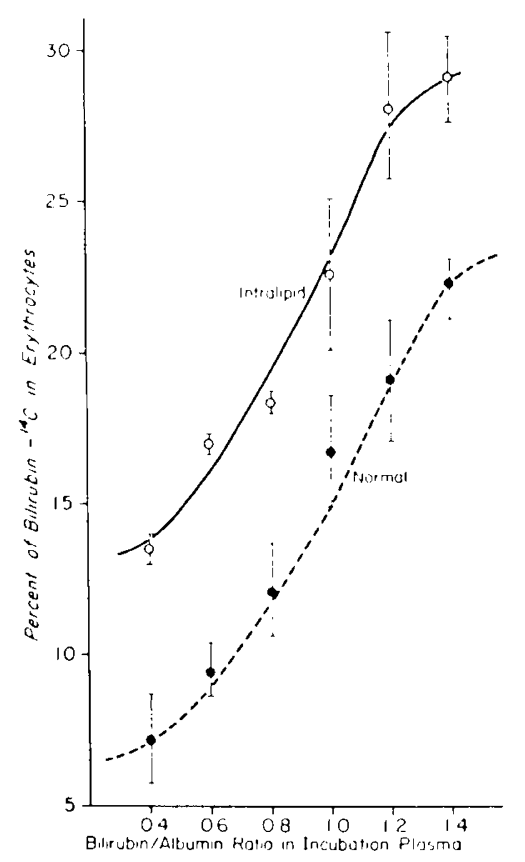

Fig. 6. Iffects of Intralipid on red blood cell uptake of bilirubin (mian $\pm S I)$ ).

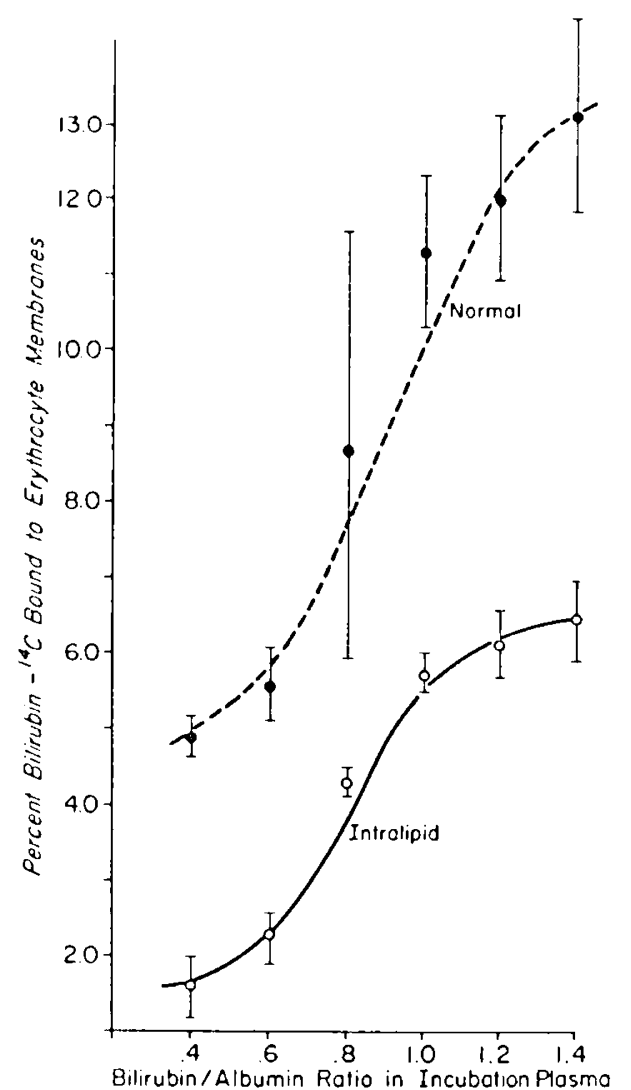

Fig. 7. Eeffect of Intralipid on red cell membranc binding of bilirubin (mean $\pm S())$.

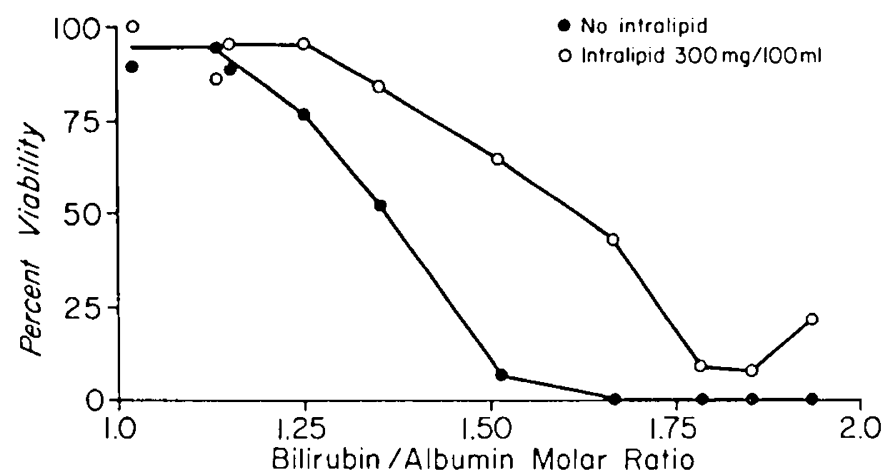

Fig. 8. Intralipid protection of tissue culture cells from bilirubin toxicity. Survival of plated L-924) cells was determined by counting cell colonies in treated and control plates 2 dayss after exposure to bilirubin

a striking increase in association of pigment with red cells. Thus, at the lowest bilirubin to albumin molar ratio tested (0.4), nearly twice as much bilirubin was carried by red cells in the presence of Intralipid. This increase in capacity of red cells for bilirubin in the presence of emulsified fat persisted at all molar ratios tested.

In contrast to results obtained with intact red cells, signiticamly less bilirubin remained bound to membranes isolated from erythrocytes exposed to Intralipid in plasma compared with controls (Fig. 7). Decreased membrane binding was observed throughout the entire range of bilirubin to albumin molar ratios from $0 .+$ to 1.4 . The differences can be explained by adsorption of Intralipid to red cell membranes; fat adsorption increatsed the bilirubin carrying capacity of red cells, but at the same time decreased the amount of pigment actually bound to ecllular elements. The halo of pigmented fat was removed by washing during the process of membrane isclation.

Intralipid inhibition of bilirubin uptake by cells was reflected in decreased cellular toxicity in tissue culture. When plated $\mathrm{L}$ cells were incubated with various molar ratios of bilirubin-albumin at concentrations compared with clinically observed values $(3 \mathrm{~g} / 100 \mathrm{ml}$ albumin. $25-50 \mathrm{mg} / 100 \mathrm{ml}$ bilirubin). Intralipid provicked considerable protection from bilirubin toxicity (Fig. 8). fifty perent cell death recurred at a bilirubin albumin molar ratio of about 1.36 (initial concentration) in the absence of Intralipid in comparison with 1.62 in the presence of $300 \mathrm{mg} /$ $100 \mathrm{ml}$ Intralipid. With an albumin concentration of $3 \mathrm{~g} / 100 \mathrm{ml}$. these bilirubin values are equivalent to total initial bilirubin concentrations of about $35 \mathrm{mg} / \mathrm{lo0} \mathrm{ml}$ and $+2 \mathrm{mg} / \mathrm{lol}(\mathrm{m} \mathrm{ml}$, respectively. The toxic threshold eccurred at a bilirubin concentration of $28 \mathrm{mg} / 100$ in control cells and at $33 \mathrm{mg} / 100 \mathrm{ml}$ in the presence of Intralipid. At the same intial bilirubin concentration. the unbound pigment was consistently lower in media contiaining Int ralipid.

\section{IDISCUSSION}

Intralipid binds bilirubin avidly, but does not interact with albumin binding sites. As such, it serves as a potential vehicle for serum transport of bilirubin, and, with the tisstes tested. Intralipid competed effectively with cells for the bilirubin pool. Our results in this respect are consistent with the observations of Chan and Schiff $(t)$, who reported minimal interaction of Intralipid with albumin binding of bilirubin as measured by Sephadex filtration and red cell uplake.

Whether Intralipid provides substantial protection from kernicterus in jaundiced human neonates will depend on the clearance of the fat particles, the clearance of the free fatty acids produced by the particle breakdown, and the fate of lipid-bound bilimbin during this process.

Experiments in jaundiced Gumn rats maty come closer to elucidating these potentially complex effects of cmulsified fat infusions on bilirubin metabolism. Rat albumin has a considerably fower affinity for bilirubin compared with human albumin 
(14). Hence, potential effects of Intralipid or of fatty acids derived from its constituents in vive on bilirubin-albumin associations should be exaggerated in rats. Injections or infusions of Intralipid produced no changes in bilirubin kinctics and distribution in blood and tissues of Gumn rats whose total pigment pool had been uniformly labeled with | ${ }^{14}(\mathrm{C}$ bilirubin (16).

Although free fatty acids are elevated in human infants receiving Intralipid, the levels attinined would be unlikely to affect the binding of bilirubin to human albumin $(5,15,17)$. especially when the fat is administered as a constant rather than periodic infusion (3).

Short of recommending Intralipid as specific therapy for hyperbilirubinemiat, our data indicate that Intralipid does not interact with albumin binding of bilirubin and should, therefore. exert little influence on bilirubin transport when the bilirubin te albumin ratio is less than unity.

\section{RI:FHELENLS AND NOTIS}

1. Borrensen, H. C.. Coran, A. G., and Knutsud, O.: Mletabolic results of parconteral fecding in neonatal surgery. Ann. Surg. 172: 201 (1970).

2. Brodersen, R., and Theilgatard, J.: Bilirubin colloid formation in neutrat agueous solution. Scand. J. (lin. Lab. Invest., 24: 395 (196(9))

3. Cashore, W. J., and Usher, R. H.: Intravenous nutrition of small premature intants. The Role of Fat in Intravemous Fecding of the Newborn, pp. 122128, ln: P. Ilahn, S. Scgal, and S. Inacts: (Pharmacia, Dorral, Quebec, $1974)$.

4. (ham, (i... and Schef, D.: In vitro studies of the relationship between Intralipid and hilirubin albumin binding. In: P. Hahn, S. Scgal. and S. Arrats: the Role of fitt in Intratenous Fecding of the Newborn, pp. 27-38. (Pharmacia. Dorral, Quebec, 1974).

5. (han, (i., Schiff, 1).. and Stern. L.: (ompetitive binding of free fatty acide and bilirubin to albumin: differences in HBAABA dye versus Sephadex $(i-25$ interpretation of results. (lin. Biochem., 4: 208 (1971).

6. Coran. A. G... and Nesbithen, R.: The metabolism of intravenously administered fat in adult and newhorn dogs. Surgery, 660 : $922(196,9)$.
7. Coran, A. G.: The intravenous use of fat for the total parenteral nutrition of the infant. Lipids, 7: 455 (1972)

8. Custafson. A., Kjellmer, I., Olegard. R., and Victorin. L. H.: Nutrition in low birth-weight infants. II. Repeated intravenous injections of falt emulsion, Acta Pediat. Scan. 63: 177 (1974).

9. Jacobsen, ., and Wennberg, R. P.: Determination of unbound bilirubin in the serum of newborns. (lin. (hem.. 20:783 (1974).

10. Kapoor. C. L., Krishna, Nurti, C. R.. and Bajpai. P. C.: Uptahe and release of bilirubin by skin. Biochem. J., 136: 35 (1975)

11. Nustafa, M. G.. and King. T. E.: Binding of hilirubin with lipid: a possible mechanism of its toxic reactions in mitochondria. J. Biol. (hem.. 245: 1084 (197(1)

12. (Ostrow, J. 1)., Hammaker, L.. and Schmid, R.: The preparation of erystalline bilirubin-1"C J. Clin. Invest. 40: 1442 (1961).

13. Pendray, M. R.: Peripheral vein fecding in infants. In: Intravenous Feeding of the Newborn, pp. 158-175. The Role of Fat in P. Hahn. S. Segal, and S. Isracls: (Pharmacia, Dorral Quebec, 1974)

14. Schmid, R., Diamond, I., Hammaker, L., and Gunderson. C. B.: Interaction of bilirubin with altumin. Nature, 206: $10+1(196.5)$

15. Starinshy, R., and Shafrir. E.: Displacement of albumin-bund bilisubin by free fatty acids: Implications for neonatal hyperbilirubinemia. Clin. (hem. Acta, 24: 311 (1971).

16. Thaler MI M and Pelger A. III. Influence of Emulsified fat infusions on bilirubin metabolism. Pediat. Res., /1:000 (1977)

17. Thiessen. J., Jacobsen. J., and Brodersen, R.: Displacement of albumin boumd bilirubin by fatty acids. Acta Patcdiat. Scand.. 61: 285 (1972).

18. Wolf, H. and Lohr H.: Fettinfusionen bei fruhgeboreicen am ersten lehenstag. M. Schr. Kinderheilh. 1/6: $262(1968)$

19. Wennberg, R. P., and Thaler. M. M.: Influence of intravenous nutricuts on bilirubin transport. I. Antono acid solutions. Pediat. Re's. ll: (0)0 (1977).

20. Wrellind, (). A.: (omplete intravenous nutrition: Theoretical and experimental bacheround. Nutr. Metabol. Suppl. 14: (1972).

21. This work was supported in part by United States Public Ilealth Service Grants IID)-0.3148 and HD)-(6) 466.5 and by United (erebral Palsy Grants R-26.3 and R-26.5.

22. Requests for reprints should be addresed to: M. A1. Thater M1. De Department of Pediatries. University of California, San Franciseo, Calif. (9+143 (USA).

23. Received for puhlication Fehruary 20, 1976

24. Accepted for publication August 26, 1976
Bilirubin malnutrition Intralipid newborns jaundice

\title{
Infuence of Entravenous Nutrients on Bilirubin Transport. IIl. Emulsified Fat Infusion
}

\author{
M. N. THALIER' AND A. PELGIER
}

Department of Pedtatrics and Liver Rese'arch Conter. L'niversity of California. San Francisco, California. USA

\section{Summary}

Infusions and injections of Intralipid were administered to congenitally jaundiced rats (Gunn) in whom the total body bilirubin pool was uniform!y labeled with radioactive bilirubin. These isotopic studies indicated that Intralipid treatment had no effect on the kinetics of bilirubin formation, transport, tissue distribution, and clearance. There were no significant differences between control and fat emulsion-treated animals in the total bilirubin pool, plasma bilirubin pool, biologic half-life of bilirubin, fractional turnover, and exponential decline in plasma bilirubin specific activity at steady state. Bilirubin concentrations in blood, plasma, liver, hidneys, brain, adipose tissue, and muscle were unaltered during the course of continuous infusions (up) to $24 \mathrm{hr}$ ) of Intralipid. These results indicate that Intralipid administered in clinically applicable doses and regimens has no discernible effects on bilirubin metabolism in jaundiced rats.

\section{Speculation}

These experimental procedures and results obtained in unperturbed animals provide a basis for studies of the effects of Intralipid infusion on bilirubin metabolism in presence of experimentally induced hypoxia, hypoglycemia, metabolic acidosis, and starvation.

The caloric needs of patients requiring parenteral alimentation can be conveniently supplied or supplemented with infusions of cmulsified fat (Intralipid (20)) infused directly inte peripheral 